\title{
HUBUNGAN PARITAS DAN KARAKTERISTIK INDIVIDU TERHADAP PEMAKAIAN ALAT KONTRASEPSI DIANTARA WANITA USIA SUBUR DI PROVINSI JAWA TIMUR TAHUN 2017
}

\author{
Relationship of Parity and Individual Characteristics \\ on the Contraception Use \\ among Childbearing Age Women in the East Java Province in 2017
}

\author{
Ratna Dwi Wulandari' dan Agung Dwi Laksono² \\ ${ }^{1}$ Fakultas Kesehatan Masyarakat, Universitas Airlangga \\ ${ }^{2}$ Puslitbang Humaniora dan Manajemen Kesehatan, Badan Litbang Kesehatan \\ Naskah masuk: 25 Maret 2020 Perbaikan: 15 Mei 2020 Layak terbit: 1 Februari 2021 \\ https://doi.org/10.22435/hsr.v24i1.3038
}

\begin{abstract}
ABSTRAK
Provinsi Jawa Timur didominasi oleh suku Jawa dan Madura. Kedua suku memiliki karakter pandangan budaya tentang jumlah anak yang banyak, yaitu banyak anak, banyak rejeki. Penelitian ditujukan untuk menganalisis hubungan paritas terhadap pemakaian alat kontrasepsi pada wanita usia subur di Jawa Timur. Penelitian menggunakan data Survei Demografi dan Kesehatan Indonesia Tahun 2017. Populasi adalah wanita usia subur (15-49 tahun) di Jawa Timur. Dengan menggunakan stratification and multistage random sampling didapatkan 5.593 responden. Selain pemakaian alat kontrasepsi dan paritas, variabel lain yang adalah tipe tempat tinggal, kelompok umur, tingkat pendidikan, status bekerja, status perkawinan, status sosioekonomi, dan kepemilikan asuransi kesehatan. Penentuan pengaruh menggunakan regresi logistik biner. Hasil penelitian menunjukkan bahwa paritas merupakan salah satu determinan pemakaian alat kontrasepsi di Jawa Timur. Wanita multipara kemungkinan 4,114 kali lebih tinggi dibanding wanita primipara untuk memakai alat kontrasepsi. Wanita pada kelompok umur 15-19 tahun memiliki kemungkinan 8,413 kali dibanding kelompok umur 45-49 tahun untuk memakai alat kontrasepsi. Sementara wanita pada kelompok umur 40-44 tahun memiliki kemungkinan 2,209 kali. Wanita berpendidikan SD-SLTP kemungkinan 3,931 kali dibanding yang tidak sekolah untuk memakai alat kontrasepsi. Sedang yang berpendidikan perguruan tinggi kemungkinan 4,957 kalidibanding yang tidak sekolah. Wanita miskin kemungkinan 1,525 kali dibanding yang paling miskin untuk memakai alat kontrasepsi. Dapat disimpulkan bahwa paritas merupakan salah satu determinan pemakaian alat kontrasepsi pada wanita usia subur di Provinsi Jawa Timur.
\end{abstract}

Kata kunci: paritas, pemakaian alat kontrasepsi, wanita usia subur, keluarga berencana.

\section{ABSTRACT}

East Java Province, which is dominated by Javanese and Madurese, has a community with cultural characteristics that consider having a large number of children will many fortunes. This study aimed to analyze the relationship of parity on the use of contraceptives in women of childbearing age in East Java. The study used data from the 2017 Indonesian Demographic and Health Survey. The population was women of reproductive age (15-49 years) in East Java. By using stratification and multistage random sampling obtained 5,593 respondents. In addition to the use of contraceptives and parity, other variables were the type of residence, age group, level of education, work status, marital status, socioeconomic status, and health insurance ownership. Determination of influence using binary logistic regression. The results showed that parity was one of the determinants of contraceptive use in East Java. Multiparous women of childbearing age were 4.114 times higher than primiparous women for contraception. Women in the 15-19 age group

Korespondensi:

Ratna Dwi Wulandari

Fakultas Kesehatan Masyarakat Universitas Airlangga

E - mail : ratna-d-w@fkm.unair.ac.id 
were 8.413 times more likely to use contraception than the 45-49 year age group. While women in the age group 40-44 years have the possibility of 2.209 times. Women with an elementary-junior high school education were 3.931 times more likely than those without school to use contraception. While those with tertiary education are likely 4.957 times compared to those not in school. Poor women were 1.525 times more likely than the poorest to use contraception. It could be concluded that parity was one of the determinants of contraceptive use in women of childbearing age in East Java Province.

Keywords: parity, contraceptive use, childbearing age women, family planning.

\section{PENDAHULUAN}

Proyeksi jumlah penduduk tahun 2020 di Indonesia berdasarkan hasil Survei Penduduk Antar Sensus (SUPAS) tahun 2015 adalah sebanyak 269,6 juta jiwa. Dalam jumlah tersebut, Provinsi Jawa Timur menduduki ranking ke-2, setelah Provinsi Jawa Barat, sebagai penyumbang jumlah penduduk terbanyak (Badan Pusat Statistik, 2018). Dalam kerangka pembangunan mewujudkan masyarakat sehat dan sejahtera, banyaknya jumlah penduduk di suatu wilayah menjadi tantangan tersendiri. Wilayah dengan populasi penduduk yang padat cenderung memiliki risiko kesehatan berupa penularan penyakit dengan potensi epidemi seperti infeksi pernapasan akut, meningitis, tifus, kolera, scabies, dan penyakit lain sejenis (World Health Organization, 2020). Meningkatnya jumlah penduduk, membuat populasi semakin padat, sehingga masalah kesehatan yang muncul juga semakin banyak. Sebuah penelitian di Belanda oleh Beenackersa mengkonfirmasi adanya hubungan yang cukup kuat antara tingkat kepadatan populasi dengan tingkat kematian (Beenackersa et al., 2018).

Beberapa kondisi di atas menjadi alasan kuat perlunya dilakukan pengendalian perkembangan penduduk. Selama ini metode yang dipandang efektif untuk mengendalikan pertumbuhan penduduk adalah dengan penggunaan alat kontrasepsi. Program keluarga berencana telah menjadi salah satu program prioritas di berbagai negara. Beberapa negara telah memiliki angka cakupan penggunaan alat kontrasepsi lebih dari 80\% diantaranya Argentina, Canada, Columbia, China, Czechia, dan Finlandia. Di Indonesia, secara nasional penggunaan alat kontrasepsi baru berada pada angka 61,0\% (Population Reference Bureau, 2020). Artinya, pemerintah Indonesia masih harus bekerja keras untuk meningkatkan cakupan penggunaan alat kontrasepsi. Hal ini menjadi penting, karena akses universal ke layanan kesehatan dan hak kesehatan reproduksi, termasuk keluarga berencana, merupakan salah satu prioritas dalam Agenda for Sustainable Development 2030 (De Vargas Nunes Coll et al., 2019).

Penting untuk memahami alasan mengapa beberapa wanita usia subur tidak menggunakan alat kontrasepsi. Beberapa wanita usia subur, baik yang sudah menikah maupun tidak menikah, memiliki alasan yang beraneka ragam ketika ditanya mengapa mereka tidak menggunakan alat kontrasepsi meskipun sebenarnya tidak sedang menunggu kehamilan. Diantaranya karena ketakutan akan efek samping penggunaan alat kontrasepsi, postpartum amenorrhea, merasa aman dari kehamilan karena sedang menyusui, dan merasa jarang melakukan hubungan seks. Kurangnya pengetahuan mengenai alat kontrasepsi menjadi pemicu munculnya berbagai hal tersebut (Population Reference Bureau, 2020).

Penelitian di berbagai negara menemukan bahwa salah satu faktor yang memiliki keterkaitan erat secara umum dengan keluarga berencana, atau secara khusus dengan pemakaian alat kontrasepsi adalah paritas (Hiremath et al., 2018; Bhandari et al., 2019; Srinivas and Murali, 2019). Paritas didefinisikan sebagai berapa kali seorang wanita melahirkan janin dengan usia kehamilan 24 minggu atau lebih, terlepas dari apakah anak itu lahir hidup atau lahir mati. Tingginya paritas membawa risiko pada meningkatnya komplikasi ibu dan bayi baru lahir, seperti malpresentasi, cairan bernoda meconium, plasenta previa dan skor Apgar rendah (Al-Shaikh et al., 2017). Hal inilah yang menjadi dasar dikeluarkannya himbauan agar wanita multipara selalu mengakses alat kontrasepsi. 
Tetapi sayangnya, kesadaran masyarakat mengenai hal ini masih rendah. Banyak wanita di negara berkembang, termasuk sebagian besar wanita multipara, tidak menggunakan kontrasepsi karena berbagai alasan (Solanke et al., 2018; Herowati and Sugiharto, 2019). Oleh karena itu analisis tentang penggunaan alat kontrasepsi pada wanita usia subur dikaitkan dengan paritas penting dilakukan agar upaya memasifkan program Keluarga Berencana (KB) bisa lebih berhasil.

Bagi Provinsi Jawa Timur yang didominasi oleh suku Jawa dan Madura yang memiliki karakteristik budaya banyak anak, banyak rejeki (Kristiana et al., 2012; Widyasari et al., 2012; Kasnodihardjo, 2014), mensukseskan program KB perlu strategi yang spesifik. Dengan diperolehnya informasi tentang pola penggunaan alat kontrasepsi antar kelompok paritas, yang disertai dengan telaah mendalam pada variabel tempat tinggal, kelompok umur, tingkat pendidikan, status bekerja, status perkawinan, status sosioekonomi, dan kepemilikan asuransi kesehatan, maka hasil penelitian ini akan mampu menyajikan gambaran yang komprehensif penggunaan alat kontrasepsi di kalangan wanita usia subur di Jawa Timur. Berdasarkan latar belakang inilah maka tujuan penelitian adalah untuk menganalisis pengaruh paritas dan karakteristik individu terhadap pemakaian alat kontrasepsi pada wanita usia subur di Jawa Timur.

\section{METODE}

\section{Sumber Data}

Analisis pada studi ini dilakukan dengan mengolah data sekunder dari Survei Demografi dan Kesehatan Indonesia Tahun 2017 (SDKI 2017) untuk Provinsi Jawa Timur. Unit analisis yang digunakan adalah wanita usia subur (15-49 tahun). Pengambilan sampel SDKI 2017 dilakukan dengan menggunakan stratification and multistage random sampling, sehingga didapatkan sampel wanita usia subur di Jawa Timur sebanyak 5.593 responden.

\section{Analisis Data}

Pemakaian alat kontrasepsi adalah pengakuan responden atas pemanfaatan alat kontrasepsi pada saat diwawancara. Alat kontrasepsi adalah alat atau metode yang dipergunakan untuk mencegah atau menjarangkan kehamilan. Pada penelitian ini kontrasepsi meliputi seluruh alat/metode kontrasepsi modern, yang terdiri dari pil, diafragma, kondom wanita, foam/jelly, suntik, IUD, sterilisasi, dan implan.

Paritas adalah pengakuan responden atas jumlah anak hidup yang pernah dilahirkan. Pada penelitian ini paritas dibagi menjadi dua, yaitu primipara $(<2$ anak), dan multipara $(\geq 2$ anak).Variabel lain yang dianalisis sebagai variabel independen adalah tempat tinggal, kelompok umur, tingkat pendidikan, status bekerja, status perkawinan, status sosioekonomi, dan kepemilikan asuransi kesehatan.

Tempat tinggal dibagi menjadi dua kriteria, perkotaan dan pedesaan, berdasarkan kriteria yang ditentukan oleh Badan Pusat Statistik. Kelompok umur dibagi menjadi 7 kelompok secara 5 tahunan, yaitu 15-19, 20-24, 25-29, 30-34, 35-39, 40-44, dan 45-49 tahun. Tingkat pendidikan adalah pengakuan responden terhadap tingkat pendidikan terakhir yang telah ditamatkan. Variabel ini dibagi menjadi 4 kriteria, seperti tidak sekolah, SD-SLTP, SLTA, dan Perguruan Tinggi.Status bekerja terbagi menjadi 2 kategori, tidak bekerja dan bekerja. Status perkawinan dibagi menjadi 2 kategori, yaitu kawin dan janda. Kawin meliputi yang sah secara hukum positif, maupun sah secara agama. Janda meliputi janda mati maupun janda cerai. Belum menikah tidak diikutkan dalam analisis karena angkanya sangat kecil, tidak memungkinan untuk dilakukan analisis.

Status sosioekonomi adalah pengakuan responden terhadap kekayaan dalam rumah tangga. Kekayaan rumah tangga dinilai berdasarkan jenis kepemilikan barang dan harganya. Kuintil kekayaan disusun berdasarkan skor rumah tangga untuk setiap orang dalam rumah tangga dan kemudian dibagi ke dalam lima kategori yang sama, yang masing-masing menyumbang $20 \%$ dari populasi berdasarkan distribusi. Kategori kuintil kekayaan terdiri kuintil 1 (paling miskin), kuintil 2 (miskin), kuintil 3 (menengah), kuintil 4 (kaya), dan kuintil 5 (paling kaya)(Karaoglan and Saraçoglu, 2020; Laksono, Paramita and Wulandari, 2020). Kepemilikan asuransi kesehatan adalah kepemilikan atas asuransi apapun yang mengcover kesehatan. Terbagi atas 2 kategori, tidak memiliki dan memiliki asuransi kesehatan. 
Pada tahap awal dilakukan uji kolinieritas untuk memastikan tidak adanya kolinieritas antara variabel dependen dan independen. Tahap selanjutkan dilakukan uji Chi-square untuk menseleksi variabel yang akan dilanjutkan pada tahap berikutnya. Karena sifat variabel dependen, makapada tahap analisis multivariat digunakan regresi logistik biner untuk penentuan determinan pemakaian alat kontrasepsi pada wanita usia subur di Jawa Timur. Seluruh tahapan analisis statistik menggunakan bantuan piranti lunak SPSS tipe 22.0.

\section{Prosedur}

SDKI 2017 telah lolos uji etik dari Badan Litbangkes, Kemenkes RI. Seluruh identitas responden telah dihilangkan dari set data. Responden telah menyetujui dan menandatangani persetujuan untuk terlibat dalam SDKI 2017. Peneliti telah mendapatkan izin untuk pemanfaatan data bagi keperluan analisis dalam studi ini melalui situs https://dhsprogram.com/data/new-userregistration.cfm.

\section{HASIL}

Informasi pada Tabel 1 memperlihatkan hasil uji kolinieritas antar variabel independen. Tabel 1 menunjukkan bahwa tidak ada kolinieritas. Tabel 1 menginformasikan bahwa nilai tolerance variabel independen $>0.10$. Sedang nilai VIF untuk seluruh variabel independen $<10.00$. Berdasarkan pada pengambilan keputusan dalam uji multikolinieritas dapat disimpulkan bahwa tidak terjadi gejala multikolinearitas dalam model regresi.

Tabel 1. Hasil Uji Kolinieritas $(n=5.593)$

\begin{tabular}{lcc}
\hline Variabel & Toleransi & VIF. \\
\hline Paritas & 0,801 & 1,249 \\
Tempat Tinggal & 0,812 & 1,231 \\
Kelompok Umur & 0,743 & 1,346 \\
Tingkat Pendidikan & 0,666 & 1,501 \\
Status Bekerja & 0,953 & 1,049 \\
Status Perkawinan & 0,973 & 1,028 \\
Status Sosioekonomi & 0,652 & 1,533 \\
Asuransi Kesehatan & 0,976 & 1,024 \\
\hline
\end{tabular}

Variabel terikat: Pemakaian Alat Kontrasepsi

Tabel 2 merupakan statistik deskriptif paritas responden dengan variabel lain yang berkaitan. Tabel 2 menunjukkan bahwa pada kedua kategori paritas, baik primipara maupun multipara lebih banyak wanita usia subur yang memakai alat kontrasepsi. Pada kategori primipara wanita usia subur lebih banyak tinggal di perdesaan, sedang pada kategori multipara wanita usia subur di Jawa Timurlebih banyak tinggal di wilayah perkotaan.

Tabel 2 menginformasikan bahwa pada kategori primipara wanita usia subur lebih banyak kelompok umur 25-29 tahun, sedang pada kategori multipara wanita usia subur di Jawa Timur lebih banyak kelompok umur 45-49 tahun. Pada kategori tingkat pendidikan, kedua kategori paritas, baik primipara maupun multipara lebih banyak wanita usia subur yang memiliki pendidikan SLTA.

Tabel 2 memperlihatkan bahwa kedua kategori paritas, baik primipara maupun multipara lebih banyak wanita usia subur yang berstatus kawin. Berdasarkan status sosioekonomi, pada kategori primipara wanita usia subur lebih banyak kelompok sosioekonomi menengah, sedang pada kategori multipara wanita usia subur di Jawa Timur lebih banyak kelompok paling kaya. Tabel 2 menginformasikan bahwa pada kategori primipara wanita usia subur lebih banyak wanita yang tidak memiliki asuransi kesehatan, sedang pada kategori multipara wanita usia subur di Indonesia lebih banyak wanita yang memiliki asuransi kesehatan. 
Tabel 2. Hasil Uji Bivariate antara Paritas dan Variabel yang Berkaitan pada Wanita Usia Subur di Jawa Timur(n=5.593)

\begin{tabular}{|c|c|c|c|c|c|}
\hline \multirow{2}{*}{ Variabel } & \multicolumn{2}{|c|}{ Primipara } & \multicolumn{2}{|c|}{ Multipara } & \multirow{2}{*}{$\mathbf{P}$} \\
\hline & $\mathbf{n}$ & $\%$ & $\mathbf{n}$ & $\%$ & \\
\hline Pemakaian alat kontrasepsi & & & & & ${ }^{* * *} 0,000$ \\
\hline Tidak memakai & 381 & $43,2 \%$ & 1078 & $22,9 \%$ & \\
\hline Memakai & 500 & $56,8 \%$ & 3634 & $77,1 \%$ & \\
\hline Tempat Tinggal & & & & & ${ }^{* *} 0,001$ \\
\hline Perkotaan & 423 & $48,0 \%$ & 2546 & $54,0 \%$ & \\
\hline Perdesaan & 458 & $52,0 \%$ & 2166 & $46,0 \%$ & \\
\hline Kelompok Umur & & & & & ${ }^{* * *} 0,000$ \\
\hline 15-19 tahun & 22 & $2,5 \%$ & 2 & $0,0 \%$ & \\
\hline 20-24tahun & 163 & $18,5 \%$ & 55 & $1,2 \%$ & \\
\hline $25-29$ tahun & 253 & $28,7 \%$ & 248 & $5,3 \%$ & \\
\hline 30-34tahun & 175 & $19,9 \%$ & 671 & $14,2 \%$ & \\
\hline 35-39tahun & 108 & $12,3 \%$ & 1190 & $25,3 \%$ & \\
\hline 40-44tahun & 82 & $9,3 \%$ & 1170 & $24,8 \%$ & \\
\hline 45-49tahun & 78 & $8,9 \%$ & 1376 & $29,2 \%$ & \\
\hline Tingkat Pendidikan & & & & & ${ }^{* * *} 0,000$ \\
\hline Tidak sekolah & 14 & $1,6 \%$ & 165 & $3,5 \%$ & \\
\hline SD-SLTP & 213 & $24,2 \%$ & 1967 & $41,7 \%$ & \\
\hline SLTA & 550 & $62,4 \%$ & 2123 & $45,1 \%$ & \\
\hline PT & 104 & $11,8 \%$ & 457 & $9,7 \%$ & \\
\hline Status Bekerja & & & & & ${ }^{* * *} 0,000$ \\
\hline Tidak bekerja & 387 & $43,9 \%$ & 1759 & $37,3 \%$ & \\
\hline Bekerja & 494 & $56,1 \%$ & 2953 & $62,7 \%$ & \\
\hline Status Perkawinan & & & & & ${ }^{* * *} 0,000$ \\
\hline Kawin & 810 & $91,9 \%$ & 4488 & $95,2 \%$ & \\
\hline Janda & 71 & $8,1 \%$ & 224 & $4,8 \%$ & \\
\hline Status Sosioekonomi & & & & & ${ }^{* *} 0,001$ \\
\hline Paling miskin & 92 & $10,4 \%$ & 508 & $10,8 \%$ & \\
\hline Miskin & 186 & $21,1 \%$ & 849 & $18,0 \%$ & \\
\hline Menengah & 216 & $24,5 \%$ & 959 & $20,4 \%$ & \\
\hline Kaya & 190 & $21,6 \%$ & 1072 & $22,8 \%$ & \\
\hline Paling kaya & 197 & $22,4 \%$ & 1324 & $28,1 \%$ & \\
\hline Asuransi Kesehatan & & & & & $* * * 0,000$ \\
\hline Tidak memiliki & 485 & $55,1 \%$ & 2177 & $46,2 \%$ & \\
\hline Memiliki & 396 & $44,9 \%$ & 2535 & $53,8 \%$ & \\
\hline
\end{tabular}

Keterangan: $* * \mathrm{p}<0.01 ; * * * \mathrm{p}<0.001$.

Tabel 3 merupakan tampilan output dari uji regresi logistik biner pemakaian alat kontrasepsi pada wanita usia subur di Jawa Timur. Tabel 3 menginformasikan bahwa paritas merupakan salah satu determinan pemakaian alat kontrasepsi di Jawa Timur. Wanita usia subur multipara kemungkinan 4,114 kali lebih tinggi dibanding wanita primipara untuk memakai alat kontrasepsi (OR 4,114; 95\% Cl 3,371-5,020).

Tabel 3 menunjukkan bahwa wanita usia subur pada kelompok umur 15-19 tahun memiliki kemungkinan 8,413 kali dibanding kelompok umur
45-49 tahun untuk memakai alat kontrasepsi (OR 8,413; 95\% Cl 2,760-25,645). Wanita usia subur pada kelompok umur 25-29 tahun memiliki kemungkinan 2,363 kali dibanding kelompok umur 45-49 tahun untuk memakai alat kontrasepsi (OR 2,363; $95 \% \mathrm{Cl}$ 1,793-3,115). Wanita usia subur pada kelompok umur 40-44 tahun memiliki kemungkinan 2,209 kali dibanding kelompok umur 45-49 tahun untuk memakai alat kontrasepsi (OR 2,209; 95\% Cl 1,820-2,682). Berdasarkan informasi tersebut maka semakin tua kelompok umur wanita usia subur, maka semakin kecil kemungkinan untuk memakai alat kontrasepsi. 
Tabel 3 memperlihatkan bahwa wanita usia subur yang berpendidikan SD-SLTP memiliki kemungkinan 3,931 kali dibanding wanita usia subur yang tidak sekolah untuk memakai alat kontrasepsi (OR 3,931; 95\% Cl 2,774-5,571). Wanita usia subur yang berpendidikan SLTA memiliki kemungkinan 3,961 kali dibanding wanita usia subur yang tidak sekolah untuk memakai alat kontrasepsi (OR 3,961; 95\% Cl 2,750-5,705). Wanita usia subur yang berpendidikan perguruan tinggi memiliki kemungkinan 4,957 kali dibanding wanita usia subur yang tidak sekolah untuk memakai alat kontrasepsi (OR 4,957; 95\% Cl 3,218-7,638). Informasi tersebut menunjukkan kecenderungan bahwa semakin berpendidikan wanita usia subur, maka semakin memiliki kemungkinan untuk memakai alat kontrasepsi.

Tabel 3 menunjukkan bahwa status perkawinan merupakan salah satu prediktor dari pemakaian alat kontrasepsi. Wanita usia subur yang berstatus kawin memiliki kemungkinan 59,857 kali dibanding yang janda untuk memakai alat kontrasepsi (OR 59, 857; 95\% Cl 36,122-99,187).

Tabel 3 memperlihatkan bahwa wanita usia subur yang memiliki status sosioekonomi miskin kemungkinan 1,525 kali dibanding wanita usia subur yang paling miskin untuk memakai alat kontrasepsi (OR 1,525; 95\% Cl 1,173-1,983). Wanita usia subur yang memiliki status sosioekonomi menengah kemungkinan 1,314 kali dibanding wanita usia subur yang paling miskin untuk memakai alat kontrasepsi (OR 1,314; 95\% Cl 1,013-1,703).

Tabel 3 menginformasikan bahwa kepemilikan asuransi kesehatan juga merupakan salah satu determinan dari pemakaian alat kontrasepsi pada wanita usia subur di Jawa Timur. Wanita usia subur yang memiliki asuransi kesehatan kemungkinan 1,226 kali dibanding wanita usia subur yang tidak memiliki asuransi kesehatan untuk memakai alat kontrasepsi (OR 1,226; 95\% Cl 1,068-1,407).

Tabel 3. Hasil Uji Regresi Logistik Biner Pemakaian Alat Kontrasepsi pada Wanita Usia Subur di Provinsi Jawa Timur- Indonesia Tahun 2017 (n=5.593)

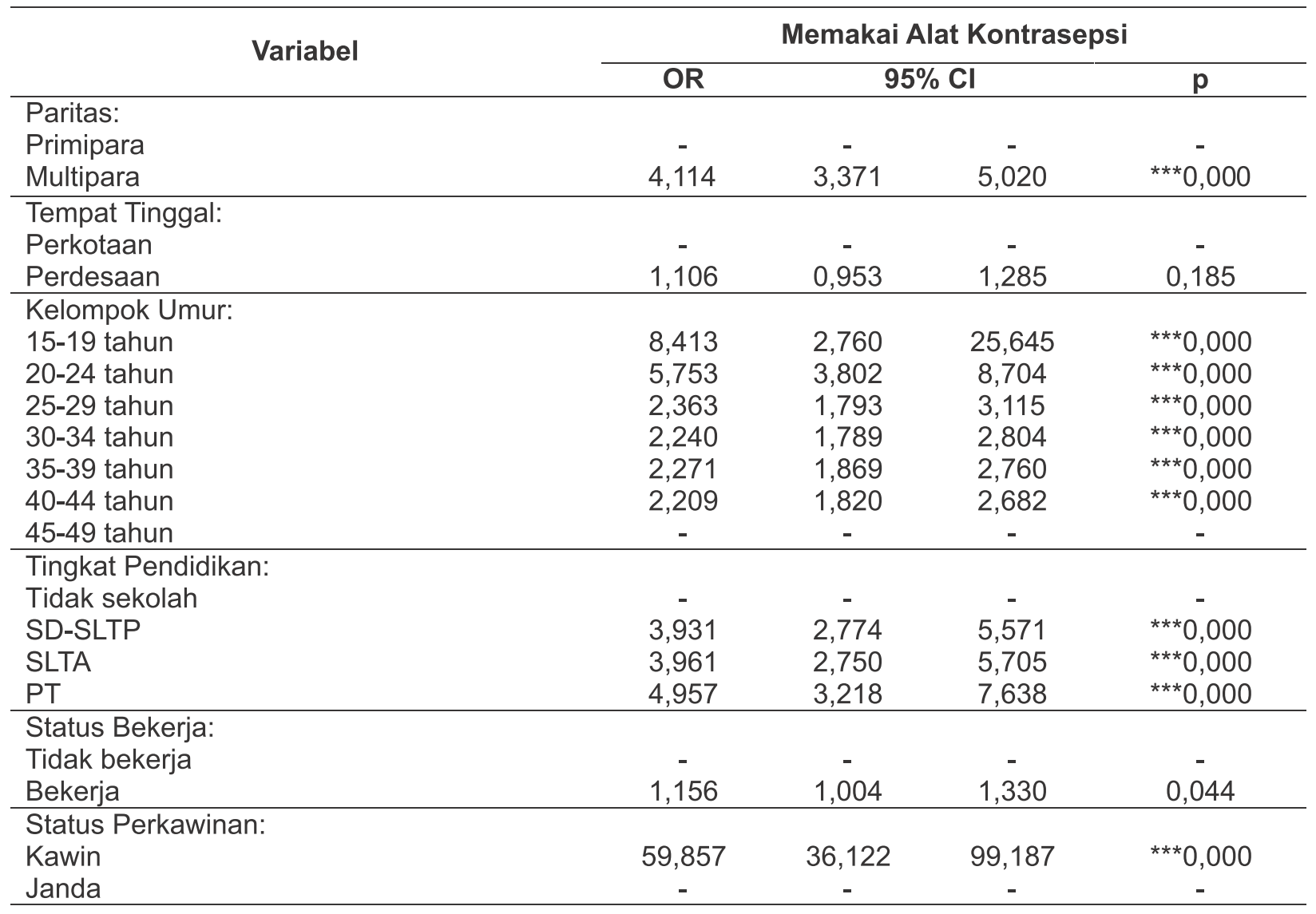




\begin{tabular}{lcccc}
\hline Status Sosioekonomi: & - & - & - & - \\
Paling miskin & 1,525 & 1,173 & 1,983 & ${ }^{* *} 0,002$ \\
Miskin & 1,314 & 1,013 & 1,703 & ${ }^{*} 0,039$ \\
Menengah & 1,020 & 0,782 & 1,329 & 0,885 \\
Kaya & 0,895 & 0,679 & 1,180 & 0,430 \\
Paling kaya & & & & \\
\hline Asuransi Kesehatan: & - & - & - & - \\
Tidak memiliki & 1,226 & 1,068 & 1,407 & ${ }^{* *} 0,004$ \\
Memiliki & & & &
\end{tabular}

Keterangan: $* p<0.05 ; * * p<0.01 ; * * * p<0.001$.

\section{PEMBAHASAN}

Hasil analisis menemukan bahwa paritas merupakan salah satu determinan dari pemakaian semua jenis kontrasepsi di Jawa Timur. Wanita usia subur multipara memiliki kemungkinan lebih baik untuk menggunakan alat kontrasepsi dibanding wanita usia subur primipara. Informasi ini menunjukkan kemungkinan bahwa wanita primipara masih menginginkan anak, sehingga belum mau menggunakan alat kontrasepsi. Temuan penelitian dengan hasil yang sejalan diinformasikan dalam sebuah meta analisis hasil Demographic and Health Survey di berbagai negara. Diinformasikan bahwa wanita primipara yang belum memiliki anak, memiliki cakupan yang rendah dalam pemakaian alat kontrasepsi (De Vargas Nunes Coll et al., 2019). Temuan ini sesuai dengan penelitian sebelumnya di Palembang (Zurizah, 2015).

Sebuah penelitian dengan variabel dependen pemakaian alat kontrasepsi mantap (Long-Acting Reversible Contraception) dilakukan di Nepal. Penelitian tersebut menginformasikan temuan yang berbeda, wanita usia subur yang memiliki dua anak atau kurang memiliki kemungkinan 1,46 kali dibanding wanita usia subur yang memiliki anak lebih dari dua untuk menggunakan kontrasepsi mantap (Bhandari et al., 2019). Temuan berbeda ditemukan dalam sebuah penelitian lain yang dilakukan di Amerika. Secara spesifik ditemukan bahwa paritas merupakan determinan dari pemakaian IUD. Wanita usia subur dengan paritas yang lebih tinggi memiliki kemungkinan lebih besar untuk menggunakan IUD (Mosher, Moreau and Lantos, 2016).

Selain paritas, kelompok umur juga ditemukan sebagai salah satu determinan pemakaian alat kontrasepsi, semakin tua kelompok umur, maka semakin kecil kemungkinan untuk memakai alat kontrasepsi.Temuan penelitian ini sejalan dengan sebuah penelitian di Burkina Faso. Penelitian tersebut menginformasikan bahwa wanita usia kurang dari 25 tahun memiliki kemungkinan lebih baik untuk menggunakan alat kontrasepsi dibanding kelompok umur yang lebih tua (Kiemtoré et al., 2019).Sebuah penelitian di India menginformasikan temuan yang sejalan, bahwa wanita usia subur yang lebih muda memiliki kemungkinan lebih tinggi untuk memakai alat kontrasepsi (Yadav et al., 2017). Sementara dua penelitian lain di India dan Amerika menginformasikan temuan yang lebih umum, bahwa umur merupakan salah satu determinan pemakaian alat kontrasepsi (Mosher, Moreau and Lantos, 2016; Hiremath et al., 2018).Temuan yang sama juga diinformasikan dalam penelitian sebelumnya di klinik kebidanan dan bidan praktik swasta di Kota Palembang (Zurizah, 2015; Junita, 2018).

Hasil analisis menemukan bahwa semakin berpendidikan wanita usia subur, maka semakin memiliki kemungkinan untuk memakai alat kontrasepsi. Hasil analisis ini menginformasikan bahwa pendidikan yang baik memberi pengertian yang lebih baik juga pada wanita untuk memahami tujuan program keluarga berencana. Hasil penelitian yang sama juga ditemukan dalam sebuah penelitian di India.Pendidikan yang lebih baik membuat wanita lebih memahami pilihan yang lebih baik untuk kesehatan reproduksinya (Yadav et al., 2017). Pendidikan yang baik juga dapat memahami dan mengatasi barier yang ada, diantaranya mitos, miskonsepsi, persepsi salah publik, dan efek samping dari pemakaian alat kontrasepsi (Ochako et al., 2015; Mushy et al., 2020). Tidak hanya pendidikan secara formal, pendidikan secara informal dengan melakukan diseminasi informasi tentang pemakaian kontrasepsi melalui media massa juga dapat meningkatkan pemakaian alat kontrasepsi (Appiah et al., 2020). Sementara di Indonesia tingkat pendidikan ditemukan turut memberi pengaruh pada pemakaian Alat Kontrasepsi dalam Rahim (AKDR) (Junita, 2018). Pendidikan yang lebih baik seringkali ditemukan memberi dampak positif pada output di bidang kesehatan (Ipa et al., 2020; 
Megatsari et al., 2020; Wulandari and Laksono, 2020a, 2020b). Sementara tingkat pendidikan yang rendah diinformasikan sebagai barier untuk mencapai kinerja di bidang kesehatan yang lebih baik (Laksono and Wulandari, 2020).

Hasil analisis menemukan bahwa status perkawinan merupakan salah satu determinan pemakaian alat kontrasepsi di Jawa Timur. Sebuah penelitian di North-Western Tanzania yang dilakukan pada wanita usia subur umur 15-19 tahun menginformasikan temuan yang sama bahwa status perkawinan merupakan determinan pemakaian alat kontrasepsi. Tetapi nilai budaya yang berbeda soal perkawinan membuat detail yang bertolak belakang. Wanita pada usia 15-19 tahun di Tanzania, belum menikah, tapi aktif secara seksual, memiliki prevalensi pemakaian alat kontrasepsi hampir empat kali lipat dibanding yang sudah menikah (Nsanya et al., 2019). Sebuah penelitian dengan sasaran yang berbeda dilakukan di Kenya. Diinformasikan bahwa dalam penelitian tersebut ditemukan status perkawinan juga merupakan determinan pemakaian alat kontrasepsi modern pada laki-laki (Ochako et al., 2017). Sebuah penelitian lain di level nasional di Indonesia menemukan informasi yang sejalan (Wulandari, Laksono and Nantabah, 2020).

Hasil penelitian menemukan bahwa wanita usia subur yang memiliki status sosioekonomi miskin dan menengah memiliki kemungkinan yang lebih baik dibanding yang paling miskin untuk memakai alat kontrasepsi. Temuan ini menginformasikan bahwa masyarakat miskin masih memiliki akses pada alat kontrasepsi, tetapi tidak bagi masyarakat paling miskin. Sebuah penelitian di Mexico menginformasikan temuan yang berbeda. Kemiskinan ditemukan sebagai barrieratau penghalang bagi pasangan usia subur untuk menggunakan alat kontrasepsi (Flores Arias et al., 2017). Hasil ini sejalan dengan penelitian di Ghana. Penelitian tersebut menginformasikan bahwa wanita usia subur di Ghana yang memiliki status sosioekonomi lebih baik memiliki kemungkinan yang lebih tinggi untuk menggunakan alat kontrasepsi, terutama jenis alat kontrasepsi modern (Agyire-Tettey et al., 2019). Penelitian sebelumnya di Indonesia menemukan informasi yang sejalan. Sosioekonomi, bersama-sama dengan umur, paritas, pendidikan, dan paparan medis, ditemukan sebagai determinan pemakaian alat kontrasepsi (Efendi et al., 2020; Laksono, Wulandari and Matahari, 2020). Pemakaian alat kontrasepsi yang rendah pada wanita usia subur yang berpendidikan rendah diinformasikan berpengaruh pada kejadian kehamilan pada usia remaja (Rohmah et al., 2020). Sosioekonomi yang rendah, atau kemiskinan, diinformasikan dalam beberapa penelitian sebelumnya sebagai barier untuk output kinerja yang lebih baik di bidang kesehatan (Wulandari and Laksono, 2020c; Wulandari, Putri and Laksono, 2020).

Hasil analisis menemukan bahwa wanita usia subur yang memiliki asuransi kesehatan memiliki kemungkinan lebih baik untuk memakai alat kontrasepsi. Informasi ini semakin menguatkan penelitian sebelumnya yang menemukan bahwa asuransi kesehatan bisa mereduksi barrier pembiayaan dalam akses kesehatan (Agustina and Izza, 2019; Wulandari et al., 2019; Gawron et al., 2020; Laksono, Paramita and Wulandari, 2020). Strategi pembiayaan yang berbeda untuk meningkatkan pemakaian alat kontrasepsi dilakukan di Pakistan. Pemerintah setempat merilis kebijakan Rabat Keluarga Berencana (Family Planning Voucher) pada wanita usia subur kategori miskin dan paling miskin, baik di wilayah perkotaan maupun perdesaan di Provinsi Punjab. Kebijakan ini dinilai efektif, sehingga dinilai layak untuk diperluas di wilayah lain di negara tersebut (Ali, Azmat and Hamza, 2018; Ali et al., 2019).

Keterbatasan dalam penelitian adalah dengan tidak melibatkan suami atau pasangan dalam studi ini. Beberapa penelitian menemukan bahwa karakteristik suami atau pasangan turut menjadi determinan pemakaian alat kontrasepsi, termasuk soal keyakinan suami (Gonie et al., 2018; Harrington et al., 2019).

\section{KESIMPULAN DAN SARAN}

\section{Kesimpulan}

Berdasarkan hasil analisis maka dapat disimpulkan bahwa paritas merupakan salah satu determinan pemakaian alat kontrasepsi pada wanita usia subur di Jawa Timur. Selain paritas, variabel lain yang ditemukan berpengaruh adalah kelompok umur, tingkat pendidikan, status perkawinan, status sosioekonomi, dan kepemilikan asuransi kesehatan.

Semakin tua kelompok umur wanita usia subur, maka semakin kecil kemungkinan untuk memakai alat kontrasepsi. Semakin tinggi pendidikan, maka semakin memiliki kemungkinan untuk memakai alat kontrasepsi. Wanita usia subur yang berstatus kawin memiliki kemungkinan lebih baik untuk memakai alat kontrasepsi dibanding yang berstatus janda. Wanita usia subur yang memiliki status sosioekonomi miskin dan menengah memiliki 
kemungkinan lebih baik dibanding wanita usia subur yang paling miskin untuk memakai alat kontrasepsi. Wanita usia subur yang memiliki asuransi kesehatan memiliki kemungkinan lebih baik untuk memakai alat kontrasepsi.

\section{Saran}

Berdasarkan kesimpulan tersebut maka dapat direkomendasikan pada pengambil kebijakan keluarga berencana (BKKBN) di Jawa Timur untuk fokus pada target sasaran sesuai hasil penelitian ini. Target sasaran tersebut adalah wanita usia subur yang paling miskin, tidak sekolah dan tidak memiliki asuransi kesehatan. Target sasaran tersebut adalah kelompok paling rentan untuk tidak menggunakan alat kontrasepsi. Kebijakan yang berfokus pada kelompok target dengan karakteristik seperti ini diperlukan untuk akselerasi cakupan pemakai alat kontrasepsi.

\section{UCAPAN TERIMA KASIH}

Penulis mengucapkan terima kasih kepada Inner City Fund (ICF) International yang telah menyediakan data SDKI tahun 2017 yang dijadikan dasar analisis studi ini.

\section{KONTRIBUSI PENULIS}

Ratna Dwi Wulandari dan Agung Dwi Laksono merupakan kontrobutor utama dalam artikel ini. Keduanya bersama-sama menyusun konsep penelitian sampai dengan penyelesaian naskah.

\section{DAFTAR PUSTAKA}

Agustina, Z. A. and Izza, N. (2019) 'Sistem Pembayaran Kolektif Peserta Mandiri dengan Status Kepesertaan dan Kepatuhan Pembayaran luran BPJS Kesehatan di Kabupaten Malang', Buletin Penelitian Sistem Kesehatan, 22(1), pp. 44-53. doi: 10.22435/hsr. v22i1.157.

Agyire-Tettey, F. et al. (2019) 'Trends and determinants of socioeconomic inequalities in sexual and reproductive health among women in Ghana', International Journal of Development Issues, 18(2), pp. 209-228. doi: 10.1108/IJDI-12-2018-0198.

Al-Shaikh, G. et al. (2017) 'Grand multiparity and the possible risk of adverse maternal and neonatal outcomes: a dilemma to be deciphered', BMC Pregnancy Childbirth, 17(1), p. 310. doi: 10.1186/s12884-017-1508-0.

Ali, M. et al. (2019) 'Are family planning vouchers effective in increasing use, improving equity and reaching the underserved? An evaluation of a voucher program in Pakistan', BMC Health Services
Research, 19(1), p. Article number 200. doi: 10.1186/s12913-019-4027-z.

Ali, M., Azmat, S. K. and Hamza, H. B. (2018) 'Assessment of modern contraceptives continuation, switching and discontinuation among clients in Pakistan: Study protocol of 24-months post family planning voucher intervention follow up', BMC Health Services Research, 18(1), p. Article number 359. doi: 10.1186/s12913-018-3156-0.

Appiah, F. et al. (2020) 'Trends and determinants of contraceptive use among female adolescents in Ghana: Analysis of 2003-2014 demographic and Health Surveys', SSM - Population Health. Elsevier Ltd, 10, p. 100554. doi: 10.1016/j.ssmph.2020. 100554.

Badan Pusat Statistik (2018) Proyeksi Penduduk Indonesia 2015-2045. Jakarta.

Beenackersa, M. A. et al. (2018) 'Urban population density and mortality in a compact Dutch city: 23year follow-up of the Dutch GLOBE study', Health \& Place, 53, pp. 79-85. doi: 10.1016/j.healthplace. 2018.06.010.

Bhandari, R. et al. (2019) 'Long acting reversible contraception use and associated factors among married women of reproductive age in Nepal', PLoS ONE, 14(3), p. Article number e0214590. doi: 10.1371/journal.pone.0214590.

Efendi, F. et al. (2020) 'Determinants of contraceptive use among married women in Indonesia', F1000Research, 9, p. Article number 193. doi: 10.12688/f1000research.22482.1.

Flores Arias, M. L. et al. (2017) 'Barriers to use of family planning methods among heterosexual Mexican couples', Research and Theory for Nursing Practice, 31(2), pp. 107-120. doi: 10.1891/1541-6577.31. 2.107.

Gawron, L. M. et al. (2020) 'The effect of a no-cost contraceptive initiative on method selection by women with housing insecurity', Contraception, 101(3), pp. 205-209. doi: 10.1016/j.contraception. 2019.11.003.

Gonie, A. et al. (2018) 'Determinants of family planning use among married women in bale eco-region, Southeast Ethiopia: A community based study', BMC Women's Health, 18(1), p. Article number 50. doi: 10.1186/s12905-018-0539-7.

Harrington, E. K. et al. (2019) 'Engaging men in an mHealth approach to support postpartum family planning among couples in Kenya: A qualitative study', Reproductive Health, 16(1), p. Article number 17. doi: 10.1186/s12978-019-0669-x.

Herowati, D. and Sugiharto, M. (2019) 'Hubungan Antara Kemampuan Reproduksi, Kepemilikan Anak, Tempat Tinggal, Pendidikan Dan Status Bekerja Pada Wanita Sudah Menikah Dengan Pemakaian Kontrasepsi Hormonal Di Indonesia Tahun 2017', Buletin Penelitian Sistem Kesehatan, 22(2), pp. 91-98. doi: 10.22435/hsr.v22i2.1553.

Hiremath, R. N. et al. (2018) 'Contraceptive use and its determinants amongst armed forces personnel', 
Medical Journal Armed Forces India, 74(2), pp. 103-107. doi: 10.1016/j.mjafi.2016.12.007.

Ipa, M. et al. (2020) 'Variation of preventive practices and its association with malaria infection in eastern Indonesia: Findings from community-based survey', PLoS ONE, 15(5), p. e0232909. doi: 10.1371/journal. pone.0232909.

Junita, D. (2018) 'Faktor-Faktor yang Berhubungan dengan Penggunaan Kontrasepsi AKDR (Alat Kontrasepsi Dalam Rahim) di BPS Rosmala Aini Palembang Tahun 2018', SCIENTIA JOURNAL, 7(1), pp. 32-37.

Karaoglan, D. and Saraçoglu, D. S. (2020) 'Women's socioeconomic status and choice of birth control method: An investigation for the case of Turkey', Journal of Biosocial Science, In press, p. In press. doi: $10.1017 /$ S0021932020000103.

Kasnodihardjo (2014) 'Nilai Anak dalam Keluarga dan Upaya Pemeliharaan Kesehatannya (Value of Children in The Family and Health Care)', Jurnal Ekologi Kesehatan, 13(4), pp. $354-362$.

Kiemtoré, S. et al. (2019) 'Factors limiting the use of modern contraceptive methods in mothers with children aged 12-23 months at the yalgado ouedraogo university hospital in Ouagadougou, Burkina Faso', Medecine et Sante Tropicales, 29(2), pp. 200-205. doi: 10.1684/mst.2019.0899.

Kristiana, L. et al. (2012) Buku Seri Etnografi Kesehatan Ibu dan Anak 2012; Etnik Jawa, Desa Gading Sari, Kecamatan Sanden, Kabupaten Bantul, Provinsi Daerahlstimewa Yogyakarta. Jakarta: Badan Peneli an dan Pengembangan Kesehatan, Kementerian Kesehatan Republik Indonesia. Available at: https://www.scribd.com/doc/ 142690361/Buku-Seri-Etnografi-Kesehatan-lbu-danAnak-2012-Etnik-Jawa-Desa-Gading-SariKecamatan-Sanden-Kabupaten-Bantul-ProvinsiDaerahlstimewa-Yogyakarta.

Laksono, A. D., Paramita, A. and Wulandari, R. D. (2020) 'Socioeconomic Disparities of Facility-Based Childbirth in Indonesia', International Medical Journal, 25(1), pp. 291-298.

Laksono, A. D. and Wulandari, R. D. (2020) 'The Barrier to Maternity Care in Rural Indonesia', J Public Health (Berl.): From Theory to Practice, p. Online First. doi: 10.1007/s10389-020-01274-3.

Laksono, A. D., Wulandari, R. D. and Matahari, R. (2020) 'The association between recent sexual activity and the use of modern contraceptive methods among married/cohabiting women in Indonesia', Journal of Public Health Research, 9(4), p. 1885. doi: https://doi.org/10.4081/jphr.2020.1885.

Megatsari, H. et al. (2020) 'The community psychosocial burden during the COVID-19 pandemic in Indonesia', Heliyon, 6(10), p. Article number e05136. doi: 10.1016/j.heliyon.2020.e05136.

Mosher, W. D., Moreau, C. and Lantos, H. (2016) 'Trends and determinants of IUD use in the USA, 2002-2012', Human Reproduction, 31(8), pp. 1696-1702. doi: 10.1093/humrep/dew117.
Mushy, S. E. et al. (2020) 'Barriers to the uptake of modern family planning methods among female youth of Temeke District in Dar es Salaam, Tanzania: A qualitative study', Sexual and Reproductive Healthcare, 24, p. Article number 100499. doi: 10.1016/j.srhc.2020.100499.

Nsanya, M. K. et al. (2019) 'Modern contraceptive use among sexually active women aged 15-19 years in North-Western Tanzania: Results from the Adolescent 360 (A360) baseline survey', BMJ Open, 9(8), p. Article number e030485. doi: 10.1136/bmjopen-2019-030485.

Ochako, R. et al. (2015) 'Barriers to modern contraceptive methods uptake among young women in Kenya: A qualitative study Global Health', BMC Public Health, 15(1), p. Article number 118. doi: 10.1186/s12889-015-1483-1.

Ochako, R. et al. (2017) 'Determinants of modern contraceptive use among sexually active men in Kenya', Reproductive Health, 14(1), p. Article number 56. doi: 10.1186/s12978-017-0316-3.

Population Reference Bureau (2020) Percent of Married Women 15-49 Using Contraception, All Methods. Available at: https://www.prb.org/international/ indicator/fp-all/map/country/ (Accessed: 25 March 2020).

Rohmah, N. et al. (2020) 'Determinants of teenage pregnancy in Indonesia', Indian Journal of Forensic Medicine and Toxicology, 14(3), pp. 2080-2085.

Solanke, B. L. et al. (2018) 'Maternal grand multiparity and intention to use modern contraceptives in Nigeria', BMC Public Health, 18, p. Article number 1207. doi: 10.1186/s12889-018-6130-1.

Srinivas, K. S. N. and Murali, R. (2019) 'A hospital based cross sectional study: Distribution of study ladies according to usage of family planning methods and previous history of hypertension', International Journal of Pharmaceutical Research, 11, pp. 75-80.

De Vargas Nunes Coll, C. et al. (2019) 'Contraception in adolescence: The influence of parity and marital status on contraceptive use in 73 low-and middleincome countries', Reproductive Health, 16(1), p. Article number 21. doi: 10.1186/s12978-019-0686-9.

Widyasari, R. et al. (2012) The 2012 Maternal and Child Health Ethnographic Series, Madura Ethnic Jrangoan Village, Omben District Sampang Regency, East Java Province (Buku Seri Etnografi Kesehatan Ibu dan Anak 2012, Etnik Madura Desa Jrangoan, Kecamatan Omben Kabupaten Sampang, Pro. Jakarta: Badan Penelitian dan Pengembangan Kesehatan, Kementerian Kesehatan RI. Available at: https://www.scribd.com/doc/142716339/Buku-SeriEtnografi-Kesehatan-Ibu-dan-Anak-2012-EtnikMadura-Desa-Jrangoan-Kecamatan-OmbenKabupaten-Sampang-Provinsi-Jawa-Timur.

World Health Organization (2020) What are the health risks related to overcrowding? Available at: https://www.who.int/water_sanitation_health/emergen cies/qa/emergencies_qa9/en/ (Accessed: 25 March 2020). 
Wulandari, R. D. et al. (2019) 'Socioeconomic Disparities in Hospital Utilization among Elderly People in Indonesia', Indian Journal of Public Health Research and Development. Surabaya, 10(11), pp. 1800-1804. doi: 10.5958/0976-5506.2019.03885.3.

Wulandari, R. D. and Laksono, A. D. (2020a) 'Determinants of knowledge of pregnancy danger signs in Indonesia', PLoS ONE, 15(5), p. Article number e0232550. doi: 10.1371/journal.pone. 0232550.

Wulandari, R. D. and Laksono, A. D. (2020b) 'Education as predictor of the knowledge of pregnancy danger signs in Rural Indonesia', International Journal of Innovation, Creativity and Change, 13(1), pp. 1037-1051.

Wulandari, R. D. and Laksono, A. D. (2020c) 'The association of socioeconomic status on early marriage among women in Rural Indonesia (Hubungan status ekonomi terhadap pernikahan dini pada perempuan di perdesaan indonesia)', Jurnal Kesehatan Reproduksi, 11(2), pp. 115-124. doi: 10.22435/kespro.v11i2.3870.115-124

Wulandari, R. D., Laksono, A. D. and Nantabah, Z. K. (2020) 'Effect of Marital Status on Completeness of Antenatal Care Visits among Childbearing Age Women in Rural Indonesia', Medico-legal Update, 20(4), pp. 2253-2258.

Wulandari, R. D., Putri, N. K. and Laksono, A. D. (2020) 'Socioeconomic Disparities in Antenatal Care Utilisation in Urban Indonesia', International Journal of Innovation, Creativity and Change, 14(2), pp. 498-514.

Yadav, K. et al. (2017) 'Determinants of non-use of family planning methods by young married women (15-24 years) living in urban slums of Uttar Pradesh', Indian Journal of Community Health, 29(1), pp. 55-66.

Zurizah, Y. (2015) 'Faktor-Faktor yang Berhubungan dengan Pemakaian Alat Kontrasepsi Intra Uterine Device (IUD) di Klinik Budi Mulia Medika Palembang Tahun 2013', Jurnal Medical Science IImu Kesehatan Akademi Kebidanan Budi Mulia Palembang, 5(1), pp. 43-55. doi: 10.35325/kebidanan.v5i1.77. 